\title{
The Role of Senior University Students' Career Adaptability in Predicting Their Subjective Well-Being
}

\author{
Oğuzhan Kırdök ${ }^{1}$, Ayten Bölükbaş1 ${ }^{1}$ \\ ${ }^{1}$ Cukurova University, Turkey \\ Correspondence: Oğuzhan Kırdök, Cukurova University, Turkey.
}

Received: February 13, 2018

Accepted: March 15, 2018

Online Published: March 29, 2018

doi:10.11114/jets.v6i5.3010

URL: https://doi.org/10.11114/jets.v6i5.3010

\begin{abstract}
The aim of this study is to examine whether career adaptability and career adaptability subscales of senior undergraduates could predict subjective well-being. The research was a descriptive correlational study which was conducted on 310 senior students (173 women, 137 men) in a state-funded university on the Mediterranean coast of Turkey and participants participated in this study voluntarily. Participants ranged in age between 20 and 28 years. Career Adaptability Scale, Life Satisfaction Scale, Positive and Negative Affect Schedule were used as data collection tools in this study. Pearson's Product-Moment Correlation Analysis, Simple Regression Analysis, and finally Multiple Regression Analysis were performed to examine the effect of the total score of career adaptability and subscale scores of careers adaptability of senior undergraduate students on subjective well-being. All analyses were conducted using the SPSS version 20.0. The findings of the research showed that career adaptability predicts the subjective well-being of university senior students. Control as a subscale of career adaptability was found to be the strongest predictive variable for subjective well-being among senior university students. Concern and confidence as subscales of career adaptability were found to be other predictive variables of subjective well-being in this study. However, curiosity as a subscale was not found to be a predictor of subjective well-being. These findings are discussed through career construction theory.
\end{abstract}

Keywords: career adaptability, subjective well-being, control, concern, curiosity, confidence

\section{Introduction}

Career which constitutes a crucial dimension of life incorporates an entire lifetime role of an individual (Herr et al., 2004). Since young people conceptualize career development as a lifelong process, young adults work for their career before they actually engage in actual work (Hartung, Porfeli, \& Vondracek, 2008). The young adulthood period is considered one of the most stressful periods due to high level of indecision and uncertainty (Kuwabara, Van Voorhees, Gollan, \& Alexander, 2007). The development of adaptive skills in this period contributes to successful negotiations (Armstong, Dedrick, \& Greenbaum, 2003). Today, due to rapid globalization and developing technology, employment and working conditions have been affected by these changes. It is more likely that the graduates of poor economic conditions comparing to better economic conditions may match up with unfavorable jobs or even face unemployment (Kahn, 2010). In addition, when individuals might not show career development appropriate for their personal characteristics and or even when they do not have a job, they may feel excluded from society owing to have unemployment status. Because of these, they become deprived of community participation and self-expression which are the main positive components of the interaction with the society (Lindsay, 2010). Studies about unemployment in terms of well-being have found that unemployed status has negative effects on individuals' well-being (Milner, Page \& LaMontagne, 2013; Paul et al., 2009). Since young adults are likely to encounter various career transitions after their graduation, they need to cope with these transitions and adapt themselves to these transitions (Murphy et al., 2010). For this reason, young adults need to develop adaptive skills that are appropriate for their career development and employment conditions (Hou et al., 2012).

Employees are required to learn and change above their industry boundaries in terms of both psychological and environmental perspective with a broader thinking system (Arthur \& Rousseau, 1996). Some theories have been developed in career counseling to help individuals who experience these kinds of changes. "Career Construction Theory" is one of these theories developed by Savickas $(1997,2005)$ with a focus of career development and benefited from "career maturity" (Super \& Kidd, 1979; Super \& Knasel, 1981; Super, 1990) but with a more emphasis on "adaptability". Career Construction Theory is a theoretical framework that aims to comprehend lifelong professional behaviors (Savickas, 
2013). Savickas evaluates career development within the framework of career construction theory and notes that career development is individuals to integrate their personal needs with social expectations and thus individuals adapt to the environment (Savickas, 2002, 2005).

To understand young adults that negotiate periods of transition such as transition from school to work and from job to job, while theory of Super (1980) emphasized "life spaces", Savickas (1997) regards career development as "construction of adaptability". In addition to this, Savickas proposed career adaptability may present individuals' career development lifelong comparing to term vocational maturity of Super. Career adaptability consists of four psychosocial sources (Savickas \& Porfeli, 2012) and Career Construction Theory emphasizes specific attitudes, beliefs and competencies in construction process (Savickas, 2013).

These sources are namely; concern, control, curiosity and confidence. Concern refers to being aware of the professional future of the individuals and plan for their future profession; control is having control for the professional future, and to construct individual career with self-discipline, effort, consistency, and awareness of individual responsibility. Curiosity is the discovery of the environment by exploring possible alternatives scenarios of the person and their possible selves. Confidence refers to self-confidence that entails one's ability to efficiently overcome vocational and career problems. These resources are qualifications that are potentially open to development (Savickas \& Porfeli, 2012).

Career adaptability is a potential skill for individuals to carry out various career tasks and is also general ability that individuals have to adapt changes in context of employment (Duffy, 2010). It is critical for university students in period of transition from school to work life to believe in their career abilities, being ready for changes and accept these changes (Wang \& Fu, 2015). Students and graduates in period of transition from school to work make decisions about the career of this new milieu that just starts after graduation (Saks, 2015). Important decisions about career are made during the university period and these decisions affect their vocational future, psychological and physiological well-being and social acceptance and general quality of life (Mann, Harmoni, \& Power, 1989). Since senior undergraduates are about to complete university education, it can be inferred that they find themselves in the process of making decisions whether they will start a new career or/and continue to do postgraduate studies. If students fail to experience a successful transition from school to work, this is likely to affect themselves and their workplace adversely and also this may lead to damage the society in terms of expenses because of unemployed status and potential problems that are likely to be accompanied afterwards (Morrison, 2002). Therefore, when young adults complete their education at university and start to work, it is necessary for them to improve their coping skills and adaptation skills (Murphy, Blustein, Bohlig, \& Platt 2010). Career adaptability is the ability of an individual to make predictions about future and to develop skills to deal with possible obstacles effectively. It is also a psychosocial construct resource that individuals have in order to fulfill their foreseen career tasks and help individuals cope with developmental tasks, vocational transition and occupational traumas. As long as individuals can anticipate these obstacles and develop solutions for these obstacles, they are able to adapt more easily in their new career (Savickas, 1997).

Career, which has an important role in various areas of individual life, includes evaluation and emotional reactions to work life. Subjective well-being comprises of individuals' cognitive evaluations about their life satisfaction in general and affects consisted of two components such as positive and negative affect (Diener, 1984). High subjective well-being score is evaluated when frequent positive emotions and less frequent negative emotions are available with a high satisfaction with life score (Diener, 1984, Myers \& Diener 1995). Although there are other factors that influence the subjective well-being of individuals, subjective well-being focuses on self-evaluation of the individual's life (Diener, 2000). In Subjective Well-being in terms of Motivation Theory, it is crucial for individuals to follow a meaningful goal to improve and maintain their subjective well-being (Brunstein, 1993). Savickas' theory of career adaptability emphasizes the personal meanings regarding to individuals' careers and presents perspectives into subjective well-being, career goals, and interrelationships of behaviors (Hartung \& Taber, 2008). It has been stated that successful adaptation to career tasks and career transitions have positive influences on work and career achievements as well as on individuals' general and professional well-being (Maggiori et al., 2013).

Savickas (2005) notes that career adaptability subscales are self-regulating resources which can also be benefited out of work environment and indeed these resources can be utilized for the challenges in daily life. With all these perspectives, career adaptability may affect well-being of individuals positively (Büyükgöze-Kavas et al., 2015). It has been stated that career adaptability can increase the chances of finding suitable jobs and thus increase career success and well-being (Skorikov, 2007; Hartung \& Taber, 2008; Hirschi 2010).

Research into career adaptability has increased in many countries in recent years (Rudolph et al., 2017) as the development of the Career Adaptability Scale (Savickas \& Porfelli, 2012). Hirschi (2009), Maggiori et al. (2013), Santilli et al., (2014, 2017) and Bölükbaşı (2017) found career adaptability predicted life satisfaction which is cognitive assessment component of subjective well-being. These findings and some other studies (Brown et al., 2012; Rossier et al., 
2012) show that career adaptability can have effect on individual well-being outside of work. The purpose of this study is to examine the role of career adaptability and also predictive power of career adaptability subscales in predicting senior university students' subjective well-being in a state-funded University in Turkey.

\section{Methodology}

\subsection{Participants}

A total of 310 senior university students (173 women $55.8 \%, 137$ men $44.2 \%)$ enrolled at a public university in the Mediterranean region of Turkey participated in this study voluntarily and without demanding any compensation. Participants ranged in age between 20 and 28 years (average age $=22.72$ and $\mathrm{SD}=1.59$ ).

\subsection{Data Collection Tools}

Subjective Well-being: Subjective well-being was measured with three measure components such as Satisfaction with Life Scale, Positive and Negative Affect Schedule based on conception of Diener (1984) and Myers and Diener (1995). Subjective well-being was considered by the following formula: Subjective Well-being $=$ (Satisfaction with Life + Positive Affects) - Negative Affects. This measurement was designed to reflect global evaluation of affect and life satisfaction of participants.

Satisfaction with Life Scale (SWLS): SWLS was developed by Diener, Emmons, Larsen, and Griffin (1985) with the aim of measuring life satisfaction. The scale consisted of 5 items self-report measure and rated on a 7-point Likert-type scale 1 (strongly disagree) and 7 (I strongly agree). Items ranged between 5 and 35. Higher scores refer to higher levels of life satisfaction. The Cronbach Alpha internal consistency coefficient of the scale was .87 and the test-retest reliability coefficient was .82 . The Turkish validity and reliability study of the scale was carried out by Köker (1991) and Yetim (1993). Köker (1991) reported a test retest consistency coefficient of .85, which was applied at three week intervals, and Yetim (1991) reported a corrected split-half value of .75 and a KR-20 value of .78. It was benefitted from Turkish form of scale by Köker for this study and the internal consistency coefficient was found to be $\alpha=.80$ in this study.

Positive and Negative Affect Schedule (PANAS): PANAS was developed to measure affect into two subscales such as positive affect and negative affect (Watson et. al., 1988). Each subscale consists of 10 items including mood-related adjectives with a 5-point Likert-type scale ranging between 1(never) and 5 (as always). The Positive Affect Subscale included active, alert, attentive, determined, enthusiastic, excited, inspired, interested, proud, and strong. The Negative Affect Subscale included afraid, ashamed, distressed, guilty, hostile, irritable, jittery, nervous, scared, and upset. Scores of responses ranged between 1 and 50 for each subscale. Responses were obtained in order to evaluate how frequently participants experience these emotions recently. Consistency Reliabilities of positive affect and negative affect were found to be .88 and .87 respectively (Watson et. al., 1988). Turkish form by Gençöz (2000) was benefitted in present study. According to the factor analysis results conducted by Gençöz (2000), the two-factor structure accounted for $44 \%$ of the total variance. The internal consistency coefficient for positive affect was .83 and for negative affect it was .86 . Test-retest consistency results were found to be .40 and .54 , respectively. The internal consistency coefficients were found to be $\alpha=.78$ for positive affect and $\alpha=.77$ for negative affect in present study.

Career Adaptability Scale (CAAS): This scale was developed by Savickas and Porfeli (2012) and aims to measure career adaptability abilities. There are 24 items in total presented in a five-point Likert-type scale ranging from 1 (not strong) and 5 (very strong). There are four subscales consisting of six items for each in the scale. These subscales are namely; concern, control, curiosity and confidence. For each subscale, a score ranging between 5 and 30 can be obtained. Higher scores from scale refer to higher levels of career adaptability. Porfeli and Savickas (2012) found internal consistency coeffienct for concern .82 , for control .80 , for curiosity .84 and .90 for confidence. This scale was adapted into Turkish language by Büyükgöze-Kavas (2014). The four-factor structure of the scale was tested by confirmatory factor analysis and the compliance value was found to be within acceptable limits $(\mathrm{x} 2=833.063, \mathrm{df}=248, \mathrm{p}<.001 ; \mathrm{x} 2 / \mathrm{df}=3.36$; RMSEA $=.060, \mathrm{SRMR}=.049 ; \mathrm{CFI}=.90)$. Cronbach Alpha internal consistency reliability coefficients were found to be .91 for the total scale and .78 for concern, .74 for control, .81 for curiosity and .81 for confidence (Büyükgöze-Kavas, 2014). The internal consistency coefficients were $\alpha=.91$ for the total score, $\alpha=81, \alpha=.76, \alpha=.75$ and $\alpha=.84$ for concern, control, curiosity and finally confidence respectively in present study.

\subsection{Data Collection}

Data were collected after the necessary standard explanations including confidentiality principle were made for the purpose of study from senior students majoring in different departments of the university in a classroom environment.

\subsection{Data Analysis}

In this study, firstly descriptive statistics including means and standard deviations were calculated. Secondly, correlations were calculated among career adaptability (also career adaptability subscales namely concern, control, curiosity and 
confidence) and subjective well-being. Thirdly, Simple Regression Analysis was conducted to see whether career adaptability total score significantly predicted subjective well-being. Fourthly, Multiple Regression Analysis was performed to examine the predictive power of concern, control, curiosity and confidence as career adaptability subscales on subjective well-being among senior undergraduate students. All analyses were conducted using the SPSS version 20.0.

\section{Results}

Correlation analysis results, means and standard deviations and number of participants applied to Career Adaptability scores and Subjective Well-being scores of senior university students in the study group are presented in Table 1.

Table 1. Correlation Values of Career Adaptability and Subjective Well-Being

\begin{tabular}{|c|c|c|c|c|c|c|}
\hline Variables & 1 & 2 & 3 & 4 & 5 & 6 \\
\hline 1.Career adaptability & - & & & & & \\
\hline 2.Concern & $.78 * *$ & - & & & & \\
\hline 3.Control & $.80 * *$ & $.49 * *$ & - & & & \\
\hline 4.Curiosity & $.81 * *$ & $.52 * *$ & $.52 * *$ & - & & \\
\hline 5.Confidence & $.86^{* *}$ & $.54 * *$ & $.63 * *$ & $.64 * *$ & - & \\
\hline 6.Subjective well-being & $.59 * *$ & $.48 * *$ & $.59 * *$ & $.35 * *$ & $.51 * *$ & - \\
\hline $\mathrm{X}$ & 89.92 & 22.38 & 23.13 & 21.81 & 22.61 & .00 \\
\hline SD & 13.45 & 4.27 & 4.02 & 3.97 & 4.18 & 2.08 \\
\hline
\end{tabular}

$\mathrm{n}=310, * * \mathrm{p}<.001$

As shown in Table 1, the participants in the study had a total score of $89.92(\mathrm{SD}=13.45)$ for career adaptability and mean scores were found to be for concern 22.38 ( $\mathrm{SD}=4.27$ ), for control 23.13 ( $\mathrm{SD}=4.02)$, for curiosity $21.81(\mathrm{SD}=3.97)$, for confidence 22.61 ( $\mathrm{SD}=4.18$ ) and finally for total score of subjective well-being .00 ( $\mathrm{SD}=2.08)$.

In addition to these, subjective well-being was seen to be correlated positively to career adaptability total score ( $\mathrm{r}=59)$, and the subscales of career adaptability namely concern $(\mathrm{r}=.48)$, control $(\mathrm{r}=.59)$, curiosity $(\mathrm{r}=.35)$ and confidence $(\mathrm{r}=.51)$. The simple regression was conducted to see whether career adaptability total score predicted subjective well-being score among senior university students. Analysis findings appear in Table 2.

Table 2. Results of Simple Regression Analysis Regarding Career Adaptability Predictor Role in Subjective Well-being

\begin{tabular}{llllllll}
\hline Variable & $B$ & St. & $\beta$ & $T$ & $\mathrm{R}$ & $\Delta \mathrm{R}^{2}$ & $\mathrm{~F}$ \\
\hline Constant & -8.302 & .645 & & $-12.878^{* *}$ & .59 & .35 & $169.542^{* *}$ \\
Career adaptability & .092 & .007 & .596 & $13.021^{* *}$ & & & \\
\hline
\end{tabular}

$* \mathrm{p}<.001$

As presented in Table 2, according to results of Simple Regression Analysis, career adaptability significantly predicted subjective well-being $(\mathrm{R}=.59, \Delta \mathrm{R} 2=.35, \mathrm{~F}=169.542, \mathrm{p}<0.01)$. In addition to this, career adaptability total score accounted for $35 \%$ of the variance in subjective well-being.

After it was seen that career adaptability total score predicted subjective well-being, multiple regression analysis was performed to examine each subscale of career adaptability predictor power in subjective well-being. Results concerning multiple regression analysis are provided in Table 3.

Table 3. Results of Multiple Regression Analysis Regarding Subscales of Career Adaptability Predicting Subjective Well-being

\begin{tabular}{lccccccc}
\hline Variable & $\mathrm{B}$ & $\mathrm{SD}$ & $\beta$ & $\mathrm{T}$ & $\mathrm{R}$ & $\Delta \mathrm{R} 2$ & $\mathrm{~F}$ \\
\hline Constant & -8.434 & .621 & & $-13.585^{* *}$ & .64 & .41 & $54.490^{* *}$ \\
Concern & .112 & .027 & .230 & $4.178^{* *}$ & & & \\
Control & .210 & .031 & .405 & $6.874 * *$ & & & \\
Curiosity & -.055 & .031 & -.104 & -1.737 & & & \\
Confidence & .099 & .033 & .199 & $3.034 * *$ & & & \\
$* \mathrm{p}<.001$ & & & & & & &
\end{tabular}

According to results of multiple regression, Table 3 reveals that career adaptability was found to be a predictor of subjective well-being $(\mathrm{R}=.64, \Delta \mathrm{R} 2=.41, \mathrm{~F}=54.490, \mathrm{p}<0.01)$. Career adaptability accounted for $41 \%$ of the variance in subjective well-being. As for career adaptability subscales, control $(\beta=.405, \mathrm{p}<.001)$ was the strongest predictor of subjective well-being accompanied by concern $(\beta=.230, \mathrm{p}<.001)$ and confidence $(\beta=.199, \mathrm{p}<.001)$. However, curiosity $(\beta=-.104)$ as a subscale of career adaptability was not found to be a predictor of subjective well-being among senior university students in this study. 


\section{Discussion and Conclusion}

The aim of this study was to examine career adaptability and subscales of career adaptability predictive power in subjective well-being among senior university students. The findings of the research showed that career adaptability predicts the subjective well-being of university senior students in present study. In line with some studies, control as a subscale was found the strongest predictor of subjective well-being (Konstam et al., 2015). In addition to this, control also was found to have the highest score among other career adaptability subscales in the study of validation of Turkish form of Career Adaptability Scale (Büyükgöze-Kavas, 2014) and this finding can be supported by a career adaptability study conducted by Hamtiaux and et al., 2013.

The control as a subscale of career adaptability is the expression of the ability of individuals who take responsibilities for themselves and their behavior. This concept includes variables such as decision making, locus of control, self-confidence, and autonomy (Savickas, 2005). Young adults in the period of transition from school to work may feel less able to control changes in their environment, but they may much better adapt to the challenges of career development if they perceive themselves to have control over these changes (Konstam et al., 2015). The fact that the ability of control is high helps individuals to have self-discipline, effort, determination and responsibility to organize themselves and their environment (Savickas and Porfeli, 2012). Büyükgöze-Kavas (2014) in a study conducted with Turkish students stated that control was found to have the highest score as a subscale of career adaptability and author interpreted this finding with education system in Turkey. There is an exam called the Public Personnel Selection Examination, which should be taken to work in public institutions providing "regular income, certain working hours and vacation opportunities". There is an increasing demand for working in public institutions with these characteristic works especially after university graduation in Turkey. As this present study was conducted with Turkish university students, it can be inferred that our finding is consistent with this. In Hirschi's (2009) study, career adaptability predicted life satisfaction and one's control in his/her life. In addition, Duffy (2010) found that variables that may be relevant for individuals with high levels of control are social support, self-esteem and optimism, and that if there is not a strong sense of control in the individual, they may experience a decline in career adaptability.

Savickas (2005) considers curiosity as being enterprising about collecting information for demanded work types and work opportunities. Curiosity as a subscale was not a predictor of subjective well-being in this research. The reason for this is might be because of what an individual mostly seeks in career life is regular income, employment and regular working hours in Turkey. These kinds of works are mostly important and even primary for individuals in Turkey recently. Because of this, they may tend not to explore other career choices and are not interested in new possible opportunities in their career. According to a counseling needs analysis study conducted in Turkey (Yerin-Güneri \& Çapa-Aydın, 2012) concern was found to be the most pressing factor for unemployment and transition period to career life for young adults. Young people who want to have a work may not need to search for other career options as they focus on certain jobs with "stable" characteristics and as a result of this, the curiosity may be considered not to have predicted subjective well-being in present study.

Concern and confidence as subscales of career adaptability were found to be predictive variables of subjective well-being in this study. Within the framework of career construction theory, confidence reflects the ability of individuals to perform their tasks effectively and successfully, to learn new skills and to cope with challenges (Savickas, 2002, 2012). Concern refers to being fore-sighted and the ability of preparing for future career (Savickas, 1997). Career concern supports career planning and positive attitudes towards optimism whereas indifference which is likely to reflect when concern is a lack of resource reflects lack of planning and hopelessness towards the future (Savickas, 2005).

Some studies about career adaptability reveals that career adaptability have positive influence on both output at work and individual well-being (Brown et al., 2012; Rossier et al., 2012; Maggiori et al., 2013) and consistent with these, it can be inferred that senior undergraduates feel happier as the level of their career adaptability increase in present study. Today, it is very rare that individuals can work life-long in the same job (Savickas, 2006; Watss, 2008). On the other hand, when we consider the career process as a continuing concept, employees should continue to adapt to changing demands and opportunities in work context to remain as efficient and profitable employees (Porfeli \& Vondracek, 2009). From perspective of career adaptability as self-regulatory resources that can be used to struggle against the difficulties in daily life as it happens in work life (Savickas, 2005), the current findings point out that the sources of career adaptability that individuals have are positively influencing subjective well-being. Although the importance of career adaptability and subjective well-being took interest in a study with unemployed emerging adult sample in a Western country before (Konstam et al., 2015), our study was conducted in a non-Western country such as Turkey with people near to collectivism but still with a struggle towards individualism (Mocan-Aydın, 2000). In addition to this, we believe that to increase career adaptability and hence subjective well-being during university education even before university would help individuals get ready to deal with ambiguities and challenges beforehand and this readiness may prevent them from having an unemployed status in the future as well. Thus, we can suggest career counseling centers at university should consider 
having activities to increase career adaptability skills not just for work life of students but also individual subjective well-being. Furthermore, career counselors and educators should find effective ways to improve university students' curiosity to promote higher adaptive abilities.

The limitation of this study is that it only took place at a public university in the Mediterranean region and did not include other class levels at the university, genders and age as socio-demographic variables. Future studies can be carried out in different cultures including gender and age factors. Also, future studies might examine the role of career adaptability with different positive psychology variables to compare employees and unemployed individuals. Furthermore, different departments from both public and private university students can be incorporated into the study to increase the generalization of the study.

\section{References}

Armstrong, K. H., Dedrick, R. F., \& Greenbaum, P. E. (2003). Factors associated with community adjustment of young adults with serious emotional disturbance: A longitudinal analysis. Journal of Emotional and Behavioral Disorders, 11, 66-76. https://doi.org/10.1177/106342660301100201

Arthur, M. B., \& Rousseau, D. M. (1996). A career lexicon for the 21st century. Academy of Management Executive, 10, 28-39. https://doi.org/10.5465/AME.1996.3145317

Bölükbaşı, A. (2017). Lise öğrencilerinin kariyer uyumu ve yaşam doyumu ilişkisinde iyimserlik ve umudun aracı rolü. Çukurova Üniversitesi Sosyal Bilimler Enstitüsï. Yayımlanmamış Yüksek lisans tezi.

Brown, A., Bimrose, J., Barnes, S. A., \& Hughes, D. (2012). The role of career adaptabilities formid-career changers. Journal of Vocational Behavior, 80, 754-761. https://doi.org/10.1016/j.jvb.2012.01.003

Brunstein, J. C. (1993). Personal goals and subjective well-being: A longitudinal study. Journal of Personality and Social Psychology, 65(5), 1061-1070. https://doi.org/10.1037/0022-3514.65.5.1061

Buyukgoze-Kavas, A. (2014). Validation of the Career Adapt-Abilities Scale-Turkish Form and its relation to hope and optimism. Australian Journal of Career Development, 23(3), 125-132. https://doi.org/10.1177/1038416214531931

Büyükgöze-Kavas, A., Duffy, R. D., \& Doughlass, R. P. (2015). Exploring links between career adaptability, work volition, and well-being among Turkish students. Journal of Vocational Behavior, 90. 122-131. https://doi.org/10.1016/j.jvb.2015.08.006

Diener, E. (1984). Subjective well-being. Psychological Bulletin, 95, 542-575. https://doi.org/10.1037/0033-2909.95.3.542

Diener, E. (2000). Subjective well-being: The science of happiness and a proposal for a national index. American Psychologist, 55(1), 34-43. https://doi.org/10.1037/0003-066X.55.1.34

Diener, E., Emmons, R. A., Larsen, R. J., \& Griffin, S. (1985). The satisfaction with life scale. Journal of Personality Assessment, 49, 71-75. https://doi.org/10.1207/s15327752jpa4901_13

Duffy, R. D. (2010). Sense of control and career adaptability among undergraduate students. Journal of Career Assessment, 18, 420-430. https://doi.org/10.1177/1069072710374587

Gençöz, T. (2000). Pozitif ve Negatif Duygu Ölçeği: Geçerlik ve Güvenirlik Çalışması. Türk Psikoloji Dergisi, 15(46), 19-26.

Hamtiaux, A., Houssemand, C., \& Vrignaud, P. (2013). Individual and career adaptability: Comparing models and measures. Journal of Vocational Behavior, 83, 130-141. https://doi.org/10.1016/j.jvb.2013.03.006

Hartung, P. J., \& Taber, B. J. (2008). Career construction and subjective well-being. Journal of Career Assessment, 16(1), 75. https://doi.org/10.1177/1069072707305772

Hartung, P. J., Porfeli, E. J., \& Vondracek, F. W. (2008). Career Adaptability in Childhood. The Career Development Quarterly, 57(1), 63-74. https://doi.org/10.1002/j.2161-0045.2008.tb00166.x

Herr, E. L., Cramer, S. H., \& Niles, S. G. (2004). Career guidance and counselling through the lifespan- Systematic approaches (6th edit). Boston: Allyn\& Bacon.

Hirschi, A. (2009). Career adaptability development in adolescence: Multiple predictors and effect sense of power and life satisfaction. Journal of Vocational Behavior, 74(2), 145-155. https://doi.org/10.1016/j.jvb.2009.01.002

Hirschi, A. (2010). The role of chance events in the school-to-work transition: The influence of demographic, personality and career development variables. Journal of Vocational Behavior, 77, 39-49.

https://doi.org/10.1016/j.jvb.2010.02.002 
Hou, Z., Leung, S. A., Li, X., Li, X., \& Xu, H. (2012). Career Adapt-Abilities Scale-China Form: Construction and initial validation. Journal of Vocational Behavior, 80(3), 686-691. https://doi.org/10.1016/j.jvb.2012.01.006

Kahn, L. B. (2010). The long-term labor market consequences of graduating from college in a bad economy. Labor Economics, 17(2), 303-316. https://doi.org/10.1016/j.labeco.2009.09.002

Köker, S. (1991). Normal ve sorunlu ergenlerin yaşam doyumu düzeyinin karşılaştırılması (Yüksek Lisans tezi). Ankara Üniversitesi, Sosyal Bilimler Enstitüsü, Ankara.

Konstam, V., Celen-Demirtas, S., Tomek, S., \& Sweeney, K. (2015). Career adaptability and subjective well-being in unemployed emerging adults: A promising and cautionary tale. Journal of Career Development, 42, 463-477. https://doi.org/10.1177/0894845315575151

Kuwabara, S. A., Van Voorhees, B. W., Gollan, J. K., \& Alexander, G. C. (2007). A qualitative exploration of depression in emerging adulthood: Disorder, development, and social context. General Hospital Psychiatry, 29, 317-324. https://doi.org/10.1016/j.genhosppsych.2007.04.001

Lindsay, C. (2010). In a lonely place? Social networks, job seeking and the experience of long-term unemployment. Social Policy and Society, 9, 25-37. https://doi.org/10.1017/S1474746409990170

Maggiori, C., Johnston, C.., Krings, F., Massoudi \& Rossier, J. (2013). The role of career adaptability and work conditions on general and professional well-being. Journal of Vocational Behavior, 83(3), 437-449. https://doi.org/10.1016/j.jvb.2013.07.001

Mann, L., Harmoni, R., \& Power, C. (1989). Adolescent decision-making: the development of competence. Journal of Adolescence, 12(3), 265-278. https://doi.org/10.1016/0140-1971(89)90077-8

Mann, L., Harmoni, R., \& Power, C. (1989). Adolescent decision-making: The development of competence. Journal of Adolescence, 12, 265-278. https://doi.org/10.1016/0140-1971(89)90077-8

Milner, A., Page, A., \& LaMontagne, A. D. (2013). Long-term unemployment and suicide: A systematic review and meta-analysis. PLoS ONE, 8(1), e51333. https://doi.org/10.1371/journal.pone.0051333

Mocan-Aydın, G. (2000). Western models of counseling and psychotherapy within Turkey: Crossing cultural boundaries. The Counseling Psychologist, 28, 281-298. https://doi.org/10.1177/0011000000282007

Morrison, E. W. (2002). The school-to-work transition. In D. C. Feldman (Ed.), Work careers: A developmental perspective (pp. 126-158). San Francisco, CA: Jossey-Bass.

Murphy, K. A., Blustein, D. L., Bohlig, A. J., \& Platt, M. G. (2010). The college-to-career transition: An exploration of emerging adulthood. Journal of Counseling \& Development, 88, 174-181. https://doi.org/10.1002/j.1556-6678.2010.tb00006.x

Myers, D. G., \& Diener, E. (1995). Who is happy? Psychological Science, (6), 10-19. https://doi.org/10.1111/j.1467-9280.1995.tb00298.x

Paul, K. I., Geithner, E., \& Moser, K. (2009). Latent deprivation among people who are employed, unemployed, or out of the labor force. Journal of Psychology, 143, 477-491. https://doi.org/10.3200/JRL.143.5.477-491

Porfeli, E., \& Vondracek, F. (2009). Handbook of research on adult learning and development, Chapter: Career development, work, and occupational success, Publisher: Routledge, Editors: M. C. Smith, N. DeFrates-Densch.

Rossier, J., Zecca, G., Stauffer, S. D., Maggiori, C., \& Dauwalder, J. P. (2012). Career adapt-abilities scale in a French-speaking Swiss sample: Psychometric properties and relationships to personality and work engagement. Journal of Vocational Behavior, 80, 734-743. https://doi.org/10.1016/j.jvb.2012.01.004

Rudolph, C. W., Lavigne, K. N., \& Zacher, H. (2017). Career adaptability: A meta-analysis of relationships with measures of adaptivity, adapting responses, and adaptation results. Journal of Vocational Behavior, 98, 17-34. https://doi.org/10.1016/j.jvb.2016.09.002

Saks, A. M. (2015). Job search and the school-to-work transition. In U. C. Klehe, \& E. A. J. Van Hooft (Eds.), Handbook of job loss and job search (pp. 1-29). Oxford, UK: Oxford University Press.

Santilli, S., Marcionetti, J., Rochat, S., Rochat, S., Rossier, J., \& Nota, L. (2017). Career adaptability, hope, optimism, and life satisfaction in Italian and Swiss Adolescents. Journal of career development, 1-15. https://doi.org/10.1177/0894845316633793

Santilli, S., Nota, L., Ginevra, M. C., \& Soresi, S. (2014). Career adaptability, hope and life satisfaction in workers with intellectual disability. Journal of Vocational Behavior, 85, 67-74. https://doi.org/10.1016/j.jvb.2014.02.011 
Savickas, M. L. (1997). Career Adaptability: An Integrative Construct for Life-Span, Life- Space Theory. The Career Development Quarterly, 45, 247-259. https://doi.org/10.1002/j.2161-0045.1997.tb00469.x

Savickas, M. L. (2002). Career Construction: A developmental Theory of Vocational Behvavior. In D. Brown (Ed). Career Choice and development (pp.149-205). San Francisko: Jossey-Bass.

Savickas, M. L. (2005). The theory and practice of career construction. In S.D. Brown, \& R. W. Lent (Eds.), Career Development and Counselling: Putting theory and research into work (pp.147-183). Hoboken, NJ: Wiley.

Savickas, M. L. (2006). Counseling for career construction (facilitating the storied approach in career counseling: Practical implementation). Fifteenth Australian Career Counseling Conference, Sydney, Australia.

Savickas, M. L. (2012). Life design: A paradigm for career intervention in the 21st century. Journal of Counseling and Development, 90, 12-90. https://doi.org/10.1111/j.1556-6676.2012.00002.x

Savickas, M. L. (2013). Career construction theory and practice. In S. D. Brown \& R. W. Lent (Eds.), Career development and counseling: Putting theory and research to work (2nd ed., pp. 147-186). New York, NY: Wiley.

Savickas, M. L., \& Porfeli, E. J. (2012). Career adapt-abilities scale. Construction, reliability, and measurement equivalence across 13 countries. Journal of Vocational Behavior, 80, 661-673. https://doi.org/10.1016/j.jvb.2012.01.011

Skorikov, V. (2007). Continuity in adolescent career preparation and its effects on adjustment. Journal of Vocational Behavior, 70 (1), 8-24. https://doi.org/10.1016/j.jvb.2006.04.007

Super, D. E. (1980). A life-span, life-space approach to career development. Journal of Vocational Behavior, 13, 282-298. https://doi.org/10.1016/0001-8791(80)90056-1

Super, D. E. (1990). A life-span, life-space approach to career development. In D. Brown \& L. Brooks (Eds.), Career choice and development: Applying contemporary theories to practice (2nd ed., pp. 197-261). San Francisco, CA: Jossey-Bass.

Super, D. E., \& Kidd, J. M. (1979). Vocational maturity in adulthood-Toward turning a model into a measure. Journal of Vocational Behavior, 14, 255-270. https://doi.org/10.1016/0001-8791(79)90054-X

Super, D. E., \& Knasel, E. G. (1981). Career development in adulthood: Some theoretical problems and a possible solution. British Journal of Guidance \& Counseling, 9, 194-201. https://doi.org/10.1080/03069888108258214

Wang, Z., \& Fu, Y. (2015). Social support, social comparison, and career adaptability: A moderated mediation model. Social Behavior and Personality: An International Journal, 43, 649-660. https://doi.org/10.2224/sbp.2015.43.4.649

Watson, D., Clark, L. A., \& Tellegen, A. (1988). Development and validation of brief measures of positive and negative affect: The PANAS scale. Journal of Personality and Social Psychology, 54, 1063-1070. https://doi.org/10.1037/0022-3514.54.6.1063

Yerin-Güneri, O., \& Çapa-Aydın, Y. (2012). Most pressing counseling need of Turkish university students: Current and future career concerns. Paper presented at the annual meeting of the International Association for Educational and Vocational Guidance, Mannheim, Germany.

Yetim, Ü. (1993). Life satisfaction: A study based on the organization of personal projects. Social Indicators Research, 29(3), 277-289. https://doi.org/10.1007/BF01079516

\section{Copyrights}

Copyright for this article is retained by the author(s), with first publication rights granted to the journal.

This is an open-access article distributed under the terms and conditions of the Creative Commons Attribution license which permits unrestricted use, distribution, and reproduction in any medium, provided the original work is properly cited. 